\title{
Pūrvācārya 考
}

\section{袴 谷憲昭}

I. Abhidharmakośabhāsya ( $A K B h)$ において, Pūrvācārya (先軌範師, 先旧諸師) と称されるものたちの主張が 11 籄所にわたって言及されている1）が，従来は， それらすべての籄所が当の Pūrvācārya との関連の下に一括して検討されたてと はなかったようである。問題の 11 䇢所は次項にすべて列挙するが，その中の(2) の例について, E. Frauwallner 教授は, Yaśomitra の Abhidharmakośavyākhyā (AKVy) における「Pūrvācārya とは聖 Asanga を始めとする (prabhṛti) Yogācāra たちである」といら一文に注目して，Asanga を Vasubandhu にとっての Pūrvācārya（昔の先生たち）の一人と見做しながら, それが特定の名称であるとは 考えていないために，次のよらな脚註を書き加えている2。

pūrvācāryāḥ といら表現によって Vasubandhu がなにを意味しているのかは，また 別な問題である。〔ての名称に関する〕註釈者たちの見解はそれぞれの箇所で䓕だ異っ ている。しかしながら，てのととは，Yaśomitra が Asanga をそのような古い論師と 見做していたといら我々の主張にとって最も重要となる論点を妨げるものではない。

ここで Frauwallner 教授が指摘する諸釈者たちの見解の相異についていえば, 上述と同じ(2)の箇所に対する『俱舎論記』では，Pūrvācārya が「経部先旧諸師」 あるいは「説一切有部先旧諸師」と置き代えられており3), $A K V y$ とは異った理 解を示すばかりか，てれによれば，Pūrvācārya とは，経部（Sautrāntika）であれ 説一切有部 (Sarvāstivāda) であれ，なんらかのグループの「古い論師たち」ある いは「昔の先生たち」を指す一般的な名称にしかすぎないととになる。しかるに， $A K B h$ における Pūrvācārya といら一連の用例は，かかる一般的呼称よりははる かに重い響きを持っているように思われ，AKVyの「Pūrvācārya とは聖 Asañga を始めとする Yogācāra たちである」といら説明も，単に(2)の䇢所にのみ妥当す るのではなく，更に他の箇所にも敷衍しうるのではないかといら印象を得るに到 ったのである。かかる印象は，まったく漠然とした形ではあったが，次のような 事情や経過を介して形成されたものであるてとをまず断っておかねばなるまい。

$A K V y$ は，先に指摘した $A K B h$ の11䇢所とはまったく別な箇所の記述にお いて，尋（vitarka）と伺（vicāra）の区別に関する一見解を Pūrvācārya の説とし 
て次のように紹介している。

atra Pūrv'ācāryā āhuḥ. vitarkaḥ katamaḥ. cetanāṃ vā niśritya prajñāṃ vā paryeșako mano-jalpo 'nabhyūhâbhyūhâvasthayor yathākramaṃ sā ca cittasy' audārikatā. vicāraḥ katamaḥ. cetanāṃ vā niśritya prajñāṃ vā pratyavekșako mano-jalpo 'nabhyūhâbhyūhâvasthayor yathākramam sā ca citta-sūkṣmatêti. (Wogihara ed., p. 140, $l l .13-16$ )

しかるに，この引用文は，既に荻原雲来博士や Frauwallner 教授によって指摘 されている4) ように, Asanga の Abhidharmasamuccaya (AS) 中の次のような 籄所にトレース可能なものである。

vitarkaḥ katamah / cetanāṃ vā niśritya prajñāṃ vā paryeșako mano-jalpah / sā ca cittasyâudārikatā // vicāraḥ katamaḥ / cetanāṃ vā niśritya prajñāṃ vā pratyavekṣako mano-jalpaḥ / sā ca cittasya sūkșmatā // (Gokhale ed., p. 18, ll. 15-17)

しかし，ただてれだけの事実のみであれば，乙れは従来の指摘以上の域を出な いわけであるが，乙れとほとんど同文の引用を，Mahāyānasūtrālamkāra に対す る Sthiramati や Asvabhāva の註釈中にも見出す5)に及んで，尋伺に関するて のなんの変哲も無いような一文が, 有部や経量部の伝統とは全く別途な, Yogācāraに特有な伝承のらちで育まれたものと見做さねばならないのではないかと 思らよらになったのである。しかも，ちょらどそんなととを思うょらになった後 の昭和 59 年 11 月 10 日, 本学会の学術大会 (大正大学) にて, 次項に掲げる $A K$ $B h$ の 11 箇所中の (9)の解釈にも論及した松田和信氏の Vyākhyāyukti $(V y Y)$ に ついての研究発表を拝聴する機会に恵まれた。との(9)は, Pūrvācārya の説とし て示され，しかもその内容が極めて Yogācāra の主張に酷似しているにもかかわ らず，同氏はかく判断するととをその時点で躊躇し，『俱舎論記』や『俱舎論疏』 の中国伝に従って一旦はそれを経量部説と見做したのであるが，その後の雑誌揭 載の時点では松本史朗氏の教示を入れて次のような結論を導くに至っている6)。

$A K B h$ に引用される pūrvācārya 説が唯識派の二諦説であり, かつそれが具体的に

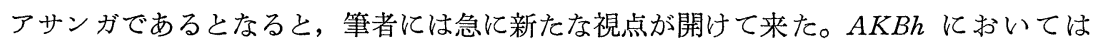
pūrvācãrya であったアサンガの説は, 次の著作である VyYにおいて, Vasubandhu 自身の二諦説となり，その後『成業論』を経て書かれた『縁起経勫』においては，アサ ンガは, pūrvācārya（過去の論師）ではなく，ただ ācārya と呼ばれるのである7)。 pūrvācārya から ācārya への呼称の変化は, Vasubandhu にとって, 何を物語ってい るのであろらか。 
松田氏が，発表の時点から雑誌掲載時までの間に Pūrvācārya に関する視点を 脹らませたのと同様なととはほぼ同じ時期の筆者にも起った8)が，公けの場での 主導権は松田氏が握っている以上，同氏の視点が完全に展開し切るまで私見を提 示するととは待ってみるのが礼儀かとも思うのであるが，開けた視点が互いにま ったく同じではない限り，仮りに今後互いの見解が競合しあったとしても，それ ぞれが無意味になるとともないと踏んで敢えて本稿を草するととにしたい。しか も，その力点は, 冒頭にも触れたように，AKBh における Pūrvācārya の名称が 11 箇所のすべてにわたって，Yogācāra のある特定できるグループの呼称として 一貫して用いられているのではないかということを作業仮設的に確認してみよう とするとてろに向けられるのみである。

II. 以下にまず, Pūrvācārya の主張として $A K B h$ 中に示される 11 箇所につ いて，その全文もしくは主要文を所出順に列挙し（各文末尾のカッコ内の頁数は, 順次に, Pradhan 本: Tib., 北京版: 玄奘訳, 大正蔵: 玄牀訳, 冠導本: 真諦訳, 大正蔵 におけるものを示す)，その後に項を改めて各々を考察してみたい。

(1) apare punar āhuh / kathaṃ tāvad ārūpyôpapannānāṃ cira-niruddhe 'pi rūpe punar api rūpam jāyate/ cittād eva hi taj jāyate na rūpāt/ evam cittam apy asmād eva sendriyāt kāyāj jāyate na cittāt / anyonya-bījakạ̣ hy etad ubhayaṃ yaduta cittạ̣ ca sendriyaś ca kāya iti Pūrvācāryāḥ / (p. 72, ll. 18-21: Gu, 88b2-4: 25 頁下 $22-26$ 行: 巻 5,7 丁裹: 184 頁中 27 行-下 3 行)

(2) yad-avasthas tad-upapatti-saṃvarttanīyam karmâkārṣit tad-avasthâtmānam tāṃś ca sattvān paśyan dhāvatîti Pūrvācāryāḥ/ (p. 127, ll. 17-18: Gu, 141a8-b1: 47 頁上 $12-13$ 行: 巻 9, 5 丁亭: 203 頁下 21-23行)

(3) vāha-yogaḥ sa tādṛśo bhavati yat kadācid vjmānasyârdham dṛṣyata iti Pūrvācāryāḥ / (p. 166, l. 17: $G u, 171 \mathrm{a}$-6 : 59 頁中 16-17行：巻 11, 9 丁裏: 216 頁 下 19-20 行)

(4) yad apy uktam "puṇyâbhiṿ̣ddhi-vacanād" iti tatrâpi Pūrvācāryā nirdiśanti “dharmatā hy eșā yathā dātṛṇāṃ dāyāḥ paribhujyante tathā tathā bhoktṛṇāṃ gunaviśeșād anugraha-viśeșāc cânya-manasām api dātṛṇām tad-ālambana-dāna-cetanābhāvitāḥ saṃtatayah sūkṣmam parināama-viśeṣaṃ prāpnuvanti yanâyatyāṃ bahutara-phalâbhiniṣpattaye samarthā bhavanti/" idam abhisaṃdhāyôktạ̣ "bhaved abhivardhata eva punyam upajāyata eva punyam" iti/ (p. 197, ll. 14-18: Gu, 195a7b3: 69 頁中 14-20 行: 巻 13,8 丁赛: 227 頁上 $21-27$ 行)

(5) Pūrvācāryā evam āhūḥ / yad dṛ̦țaṃ yat pratyakṣînrtam cakṣuṣā / śrutam 
yac chrotreṇa parataś câgamitam(sic, ākharitam)/ matạ̣ yat svayam cintitam/ vijñātam yat pratyātma-pratisaṃveditam adhigatạ̣ ca/ (p. 246, ll. 6-8: Gu, 239a 8-b : 87 頁下 $24-27$ 行 : 巻 16,16 丁裏 : 243 頁上 $14-16$ 行)

(6) prathama-kalpâsaṃkhyeya-niryāta eva bodhisattva etāṃś caturo doṣān vyāvartayati dvau ca guṇau pratilabhata iti Pūrvācāryā[ḥ]/ (p. 266, ll. 9-10: Gu, 257 a3：95 頁上 12-13 行：巻 18, 8 丁表：249 頁中 18-19 行)

(7) Pūrvācāryās tu vyācakṣate / caturṇāṃ brāhma-puṇyatvaṃ kalpaṃ svargeṣu modanāt // 124 // yāvatā punyena kalpạ̣ svargeṣu modate idạ̣ brāhmaṃ puṇyam / brahmapurohitānām kalpâyuṣkatvāt/ (p. 274, ll. 8-10: Gu, 263b5-6：97頁下 24-26 行：巻 18, 18 丁表: 252 頁下 5-8 行/13-14 行)

(8) sahajā satkāya-dṛștir avyākṛtā/ yā mṛa-pakṣinām api varttate/ vikalpitā tv akuśalêti Pūrvācāryāḥ / (p. 290, ll. 19-20: Gu, 276a8-b1：102 頁下 25-27 行：巻 19, 16 丁裹：256 頁中 24-26 行)

(9) yathā lokottareṇa jñānena gṛhyate tat-prṣṭha-labdhena vā laukikena tathā paramārtha-satyam/ yathā 'nyena tathā saṃvṛti-satyam iti Pūrvācāryāḥ // (p. 334, ll. 10-11: Ngu, 9a5-6: 116 頁中 26-28 行 : 巻 22,11 丁表: 268 頁下 29 行-269 頁上 3 行) (10) evaṃ tu sidhyati yad āhuḥ Pūrvācāryāḥ/ kathạ̣ ca Pūrvācāryā āhuh / lokottara-mārga-sāmarthyāt saṃvṛti-jñānaṃ bhāvyate yad-vyutthitaḥ satyâlambanam viśișțataram laukikaṃ jñānaṃ saṃmukhīkaroti/ (p. 406, ll. 20-22: Ngu, 60b2-3: 138 頁下 4-7 行：巻 26,15 丁裏：289 頁下 24-26 行)

(11) asty eṣa ekeșām vādaḥ/ nâiva tu Pūrvācāryā evaṃ nirdiśanti sma yāvantah prajñāntam / tasmād vicāryam etat / (p. 440, ll. 4-5: Ngu, 81a7: 147 頁中 17-18 行: 巻 28,9 丁表: 298 頁下 $22-24$ 行)

III. 以上が, $A K B h$ において Pūrvācārya の説として言及される筒所のすべ てである。もし，てれらの主張のすべてが，ある特定の Yogācāra 文献中に照合 できるならば, Pūrvācārya といら名称の持つ意味合も自ずと特定できるであろ らが，現時点で，それらすべてが完璧に照合しきれているわけではない。しかし， いまだ照合のつかない䇢所も，その可能性が極めて強いてとを衆目に曝すととに よって, 将来それらの確認が筆者と関心を等しくする人たちによって果されるて とを希らものである。以下には，そのような意味から，以上の 11 箇所について， 照合の実情や可能性について述べてみるととにしたい。

(1)については，論述の都合上後述する。

(2)は，化生 (upapāduka) の中有 (antarābhava) の地獄への生じ方に関する一説 
として示されたものであるが，記述があまりにも簡潔であるため，筆者はその意 味内容や思想史的背景を充分理解できないにもかかわらず，との説が，他説とは 異って, 地獄の生起へ導くような業をなした（tad-upapatti-samvarttanīyam karmâkarșit）点を重視しているとてろから，てれをYogācāra の文献中にトレースする 可能性は充分期待しらると同時に，先に注意した $A K V y$ のPūrvācārya とは聖 Asañga を始めとする Yogācāra たちである」といら一文は，この説に対してな されたものであるととを銘記しておく必要がある。

(3)は月の盈虧に関する一説で，てれも現時点ではトレースできていないが, $A K V y$ において Yogācāra たちの説と明記されている9）点で, 将来の検索の可 能性は充分残されている。

(4)の Pūrvācārya について $A K V y$ はなんの説明も与えていないが，この説が， 無表業に関する有部と経量部との対論によって進められる議論中で Yogācāra の 説にも論述の及ぶ箇所において示されている点に注意を喚起しなければならない。 しかも，との説は, 福業の増大を parināma-viśeșa (転変差別) に求めるものであ るが，とれを Vasubandhu が Pūrvācārya の説と見做したととは, pariṇāma-viśeșa10) といら考えが, 彼以前の, 経量部はもとより単にYogācāra 一般とも言い えないある特定のグループに由来するととを物語ってはいないであろらか。

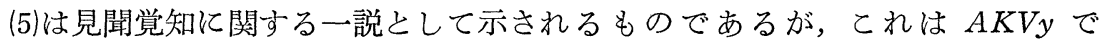
Yogācāra の規定に従ったものと言われている11) 上に, 内容的にも一致する典拠 が Yogãcārabhūmi (YBh) 中に確認できるので，それを以下に揭げておきたい。 catvāro vyavahārāḥ katame/ dṛșto vyavahāraḥ śruto mato vijñāto vyavahāraḥ / dṛșțo vyavahāraḥ katamaḥ/ yad anena bahirdhā pratyakṣīkṛtam bhavati cakṣuṣā tad upādāya yat pareșām vyavaharaty ayam ucyate dṛșṭo vyavahārah // śruto vyavahārạ̣ katamaḥ / yat paratạ̣ śrutam bhavati tad upādāya yat pareșām vyavaharati // mato vyavahāraḥ katamaḥ / yad anena na dṛșțạ̣ bhavati na śrutam api tu svayam eva cintitam tulitam upaparīkșitam tad upādāya yat pareșāṃ vyavaharati// vijñāto vyavahārạ̣ katamaḥ / yad anenâdhyātmạ̣ prativeditam bhavaty adhigatạ̣ sparśitạ̣ sākṣātkṛtam ca bhavati tad upādāya yat pareșām vyavaharaty ayam ucyate vijñāto vyavahārah // (Bhattacharya ed., p. 50, ll. 9-16)

(6)は最初の無数劫（prathama-kalpâsamkhyeya）を超えた菩薩だけが四失を転じ 二徳を得るととを主張したものであるが，ての Pūrvācārya については $A K V y$ 中に説明はなく，またとれと同文の典拠もまだ確認されていない。しかし，てて 
でいわれる四失が $A K V y$ で説明されるとおりのもの12) とすれば，その一つであ る「女たることの失 (strī-bhāva-doṣa)」は，Bodhisattvabhūmi (BBh) において, 全く同じ条件のもとで転ぜられるととになっている ${ }^{13)}$ から, 将来(6)と一致する典 拠を Yogācāra 文献に見出しうる可能性はかなり高いのではないかと思われる。

(7)は梵福 (brāhma-punya) がどのようなものかを巡る諸説の一つとして提示さ れるものであるが, $A K V y$ 中には Pūrvācārya に関する説明はなく, 類似の典拠 もまだ筆者によって確認されていない。同じ問題に関するより多くの説の列挙は 『大毘婆沙論』中に見出しらる14)が，具体的な部派名には言及していないので， それらの説をなんらかの部派に特定できるような手懸りは今のとてろまったくな い。

(8)は, Yogācāra における染污意 (klișța-manas) 説の形成史を巡る L. Schmithausen 教授の論稿において既に注意されている䇢所であり, しかもそれは同教 授によって YBh 中にトレースされている15)ので，てこでは，その指摘に従って， 両者の一致を示すに必要な章句のみを $Y B h$ より摘出しておくにとどめたい。

de (=satkāya-drșțih) 'ang rnam pa gnyis su rig par bya ste/ lhan cig skyes pa (sahajā) dang kun brtags pa (vikalpitā)'o// de la lhan cig skyes pa ni...... tha na ri dwags dang bya rnams (mṛga-pakșinām) yang yin no// kun brtags pa ni gzhan mu stegs can rnams kyi yin par blta bar bya'o// (YBh, P. ed., Zi, 112b7: D. ed., Zhi, 108a5: 大正蔵, 30 巻, 621 頁中 7-10行)

de la 'dod par spyod pa'i jig tshogs la lta ba lhan cig skyes pa (sahajā satkāyadṛ̦țiḥ) gang yin pa de ni lung du ma bstan pa (avyākṛtā) yin te/ ...... rtog pas mngon par zhen pa gang yin pa de ni mi dge ba (akuśalā) yin no// (YBh, P. ed., Zi, 115b2-3: D. ed., Zhi, 110b3-4: 大正蔵, 30 巻, 622 頁上 29-28 行)

(9)は，前述したように，松田和信氏の論稿に尽されていると思うので，すべて をそれに譲りたい。

(10)の Pūrvācārya \& $A K V y$ では説明されておらず，それらしき典拠もいまだ 確認されていないといら点では, 先の(7)の場合に準じるかもしれないが, ててで 主張されている論点は, 先の場合とは異って, 極めてはっきりしたものがある。 それは，現観後の世俗智（ābhisamayāntikam samvrṛti-jñānam）の修得がいかにして 成立するかといら問題に答えられたもので, 出世間道の能力 (lokottara-mārgasāmarthya) に基づいて世間智 (laukikam jñānam) が現前すると主張されているが, これは(9)とも関連する出世間智と後得世俗智との対応を容易に想起せしむるので， 
多少とも注意を凝らしていれば, Yogācāra 文献中に追っつけ検索可能となるの ではないかと思われる。なお，ての Pūrvācārya の説に対し，毘婆沙師 (Vaibhāșika）は異議を唱えているが，AKBh の著者 Vasubandhu はこれをむしろ肯定的 に扱っている点が注目される。

(10)は静虑支 (dhyānânga) に関する諸説を挙げた後に，Pūrvācārya はそのよう に説明していないから，「ての点がよく検討されるべきである」と結ばれている のであるが，乙の結尾を捉えて，AKVy は「ての点が『瑜伽師地論』(Yogāca ra-

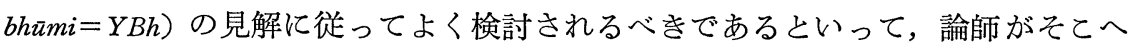
興味を促すのである16)」と註釈しているが，Pūrvācārya の説が $Y B h$ に特定され ている17)ことはとりわけ注目されてよい。

さて，最後に，論じ残した(1)に触れておかなければならない。昭和 60 年 6 月 15 日の本学会学術大会 (花園大学) にて筆者が本テーマについて口頭発表した折, 上述の全 11 箇所中, 最もYogācāra 文献中にトレースし難いと思われるものが 今問題とする(1)であるてとは卒直に表明したのであるが，同時にそれがまったく の不可能とも断定しきれない旨も付け加えておいたのであった。そのよらな両様 の推測の背景には，(1)で述べられる Pūrvācārya の説が, 所謂経量部説とされて いる色心互熏説であるとの通念が㗢いていた一方で，てのような主張は必ずしも Yogạ̄āara たちによって排斥されるとは限らないとの推測と，それに類する説を $Y B h$ 中になんとなく見たとともあるとの思いとが交差していたからなのである。 しかるに，その後の，同年 9 月に，松田和信氏の 28 日付の葉書を介して，同氏 の友人，兵藤一夫氏の教示によって，(1)の記述に類似する主張がやはり YBh に 見出しらることを知りえたので，雨氏に深謝の意を表しつつ，以下にそれを報告 しておきたい。

YBh の Viniśsayasamgrahan̄ī（「攝決択分」）においては，四縁中の因縁たる一 切種子 (sa bon thams cad pa, sarva-bijjaka) として, 所依を伴った有色根 (dbang po gzugs can rten dang bcas pa, sāśrayānîndriyāṇi rūpīṇi) と識 (rnam par shes pa, vijñāna）との二種が認められ，その後に両者互熏のあり方が説明されている ${ }^{18) か ゙ ， ~}$ この両者が(1)にいら sendriyah kāyah と citta とにそれぞれ対応しているととは 言うまでもない。しかるに，色心互熏説が徹底されたならば Yogācāara の主張す る唯識説は成り立たないのではないかといら疑念も起りうるが, Yogācāra が色 心互熏説と唯識説とを共に認めていた背景には，先の言及の少し後で，「種子が 設定されるこの仕方はアーラヤ識が設定されていない場合に知られるべきであっ 
て，〔アーラヤ識が〕設定されている場合には，要するに，そ[のアーラヤ識〕

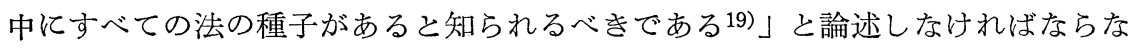
いような状況のあったてとを考慮しておく必要があろら。

IV. 以上で, $A K B h$ において Pūrvācārya の説として関説される11箇所につ いて検討を終えたが，(7)の例以外は，すべて，それらの典拠を Yogācāara 文献中 に実際上もトレースできるものか，もしくは今後そうしうる可能性の極めて高い ものかのいずれかであるととは充分示しえたのではないかと思われる。ての結果 は，AKBh の著者 Vasubandhu が，Pūrvācārya という語を任意の先生たちを指 す一般的呼称として用いていたのではなく，ある特定の思想的立場を共有してい る一群の論師たちに対する一貫した呼称として用いていたのではないかといらて とを示唆している。しかし，だからと言って，その一群の論師たちが Yoğāaāra と称せられるグループ全体と直ちに等しいのだと言うことはできまい。Vasubandhu は $A K B h$ において Pūrvācārya と Yogācāra とは一応区別して用いている からである。しかるに，AKBh における両者の呼称の使用例を比較すると，後 者 (Yogācāra) は，(4)の直前の 2 筒所，(9)の少し後の 4 箇所において用いられて いるが，前者 (Pürvācārya) よりもはるかに一般的性格が強く，むしろ「ヨーガ

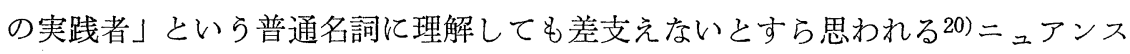
を呈す。ここで, 大胆な推測が許されるなら, 筆者は, より歴史も長くより一般 的な性格も持ちらる Yogācāara のグループ中において, そのヨーガの体験をより 理論的に体系づけようとした旧来からの一群の論師たちが Pūrvācārya と呼ばれ ていたのではないかと考えたい。しかも，Pūrvācārya とは必ず複数で現われて いる以上あくまでも複数の論師からなるグループ名と見做すべきであって，その 代表者が Asanga だったのだと見たい。それゆ光，AKVyの「聖アサンガを始 めとする (prabhrịti) Yogācāra たち」といら表現における「始めとする (prabhṛti)」 の意味は，必ずしも時間的な「始め」ではなく，代表者としての「筆頭」を表わ していると取りたいのであるが，prabhṛti の用法上かかる読みが可能かどうか識 者の比正を仰ぎたい。もしそれが可能なら, Vasubandhu が Asanga について複 数の Pūrvācārya から単数の ācārya へ呼称を変えたとする松田氏の多少苦しい 説明も不要なものになると思われるのである。

〔お詫び〕 雑誌編集の都合上, 註記は割愛せざるをえない。ただし, 註記番号は残した ので, 註記を必要とされる方は, 筆者宛に直接申し出られたい。

（駒沢大学教授） 